\title{
Report of the Ad-hoc Review of the Task Group on Global Geoscience Professionalism, September 2018
}

\author{
ARC Chair - IUGS Councilor \\ https://doi.org/10.18814/epiiugs/2019/019030
}

On 29 May 2018, the IUGS Executive Committee established an Ad-hoc Committee comprising Edmund Nickless (Chair, IUGS Councillor), Amel Barich (Secretary, IUGS Councillor), Christopher Keane (American Geosciences Institute) and Helen Pain (Royal Society of Chemistry) to review the Task Group on Global Geoscience Professionalism with the main goals of:

i. Analysing performance since the establishment of the Task Group in 2012;

ii. Assessing the alignment of the work of TGGGP with the objectives and aims of IUGS;

iii. Identifying ways to increase the impact and significance of the Task Group including concrete objectives for the near future.

We met in London at the Geological Society on 13/14 September 2018 and are grateful to the Society for hosting the meeting. In the event, Amel Barich was unable to join us because of delay in her visa application. On the first day we met with Ruth Allington, Chair, TGGGP and Isabel Fernandez, Treasurer, TGGGP, to receive a presentation and discuss with them background papers that had been provided prior to the meeting. The following day we drafted this report, which has been circulated to the Review Committee and agreed by them.

The desire to promote professionalism in the geosciences can be traced back to the so-called Flagstaff Declaration, an agreement between six organisations signed in 2008. (The American Institute of Professional Geologists, the European Federation of Geologists, the Canadian Council of Professional Geoscientists now Geoscience Canada, the Institute of Geologists of Ireland, the Geological Society of London and the llustre Colegio Oficial de Geölogos.) Despite enthusiasm, nothing concrete materialised.

The Task Group was established in 2012 following encouragement to submit a proposal, by then Secretary General, Peter Bobrowsky. That proposal had a clear set of objectives, namely:

- To facilitate collaboration between geoscientists operating in all areas of geoscience;

- To encourage rapid conversion of research findings to applied geoscience;

- To encourage greater relevancy in applied geoscience at the university level;

- To promote increased education in professional skills, including ethics, at the university level;

- To provide recommendations on priority research project design and fund allocation through greater appreciation of societal needs;

- To provide greater clarity concerning pathways and assessment criteria for geoscience graduates seeking to attain professional qualifications.

These objectives were approved unamended by the Executive Committee. Since establishment of the Task Group, progress has been reported annually but there has been no feedback from the EC about the ongoing direction of work, which has resulted that in the absence of guidance the Task Group has had no option but to set its own programme.

The absence of agreed Key Performance Indicators set at its formation makes it difficult to measure impact at this stage. Nevertheless, working with a small annual budget the Task Group has been successful in:

- Promoting and extending awareness of the concept of professionalism. As an illustration at the $34^{\text {th }}$ IGC in Brisbane there was one session; at the $35^{\text {th }}$ IGC in Cape Town there were 14 sessions held over four days;

- Engaging communities which perceive themselves to be part of 'professional practice' and in so doing meeting IUGS' inclusivity mission;

- Presenting at numerous meetings and conferences, including the $35^{\text {th }}$ and $36^{\text {th }}$ IGCs and RFG 2018;

- Building a website, but there are no clear metrics regarding usage;

- Publishing leaflets, but there are no clear metrics regarding distribution, uptake or impact;

- Growing the number of member organisations, especially during 2018.

(The annual grant to TGGGP has averaged $\$ 5000$ which has been spent principally on building a website and covering part of the expenses of speakers at major meetings. That grant has attracted gifts in kind, possibly ten or twenty-fold in value, in the form of support from employers).

A great deal has been achieved, but the current workplan is opportunistic and unfocused with no clear project completion dates. If the purpose of the then Executive Committee in establishing the Task Group was to have a proof of concept to scope what role professionalism and ethical behaviour should have within the work of the Union, then while much has been achieved, substantial amounts of work are still in process. The Task Group needs to be given more time to bring to conclusion a number of projects which are close to completion. 
Consequently, we recommend that:

- The life of the Task Group is extended by a further 3 years and that there is then a further review to decide whether and in what administrative form, possibly as a Commission, the work could continue;

- That extension is subject to submission of a Strategic Plan for approval by the Executive Committee, focussed on completing 3 or 4 well-constrained projects with clearly defined deliverables and Key Performance Indicators, to be completed within the next 3 years;

- Future requests for funding are linked to delivery of specific elements of the three-year strategy;

- The Executive Committee more actively oversees the work of the Task Group by providing feedback to submitted Annual reports.

Geoscience is a global endeavour. The mobility of the professional workforce is analogous to that of the academic community. Increasingly, because of its application in areas of societal concern, not least public safety, globally consistent professional and ethical behaviour in geoscience is being seen as a high priority, critical to the health and social relevance of our discipline and potentially an area where IUGS can have a major impact. With its international membership, the Union is in a unique position to lead and promote the subject and, in so doing, may derive considerable benefit by embracing and encouraging such a cultural change. Professional and ethical behaviour needs to be at the very heart of the Union.

We recommend that the subject should become an intrinsic part of the Core mission of IUGS and be held in as high regard as other areas of Union activity, such as the promotion of standards.

To that end, we recommend that the Executive Committee:

- Puts in place procedures to actively promote professionalism and ethical behaviour to all its adhering members and affiliated bodies;

- Declares that it expects its adhering members and affiliated bodies in turn to support professionalism and ethical behaviour among their memberships;

- Makes a commitment to promote professionalism and ethical behaviour a condition of affiliation.

The Task Group is to be congratulated in successfully promoting and extending awareness of the concept of professional and ethical practice within the wider geoscience community. However, we found little evidence that it is being given the credit for doing so. The commitment and enthusiasm of a small, dedicated executive group is exceptional. There is strong knowledge of the subject and credibility within the Task Group leadership which is energetically and competently driven. However, because the work of the Task Group is dependent on a few individuals there is a potential lack of resiliency. Sustaining activity will require a more diverse group, additional active participants and turnover of membership to ensure the Task Group is organic.

To those ends, we recommend that the Task Group:

- Continues to expand its membership, but particularly outside of Europe and North America, to ensure its work is inclusive and respectful of the diversity of geoscientists;
- Focuses on delivering a framework for the core universal definition and components of professional and ethical practice in the geosciences recognising regional differences in culture and tradition. The $36^{\text {th }}$ IGC could provide an opportunity to launch such a framework;

- Selects future activities for both impact and having regard to the available human capital resources needed to be successful;

- Recognising the current reliance on considerable volunteer effort and personal commitment of a few, gives early thought to the evolution of the current leadership team by the development of a succession plan.

We formed the impression (perhaps incorrectly) that despite all the efforts made externally, among IUGS adhering bodies and affiliated groups the work of the Task Group is poorly known. We recommend that the Task Group seeks to remedy that by submitting copy for publication in the e-newsletter and an articles to Episodes.

We are grateful to Ruth and Isabel for their good humour and patience in answering our many questions.

\section{Postscript}

The presence of two affiliated groups within the Union, the International Association for Promoting Geoethics (IAPG) and the International Association for Geoethics (IAGETH), covering the subject of geoethics is unhelpful. As a working distinction, IAGETH might be considered to deal with the philosophical aspects of geoethics and IAPG the practice. We were made aware of considerable efforts by Ruth Allington as Chair of the Task Group to work with both. So far only IAPG has been willing to collaborate and has done so most effectively as illustrated by its involvement in 7 of the 14 sessions on professionalism and geoethics held at the $35^{\text {th }}$ IGC. Advancing professional practice and geoethics needs consistency in approach and the absence of IAGETH for the work of the Task Group is to be regretted.

\section{October 2018}

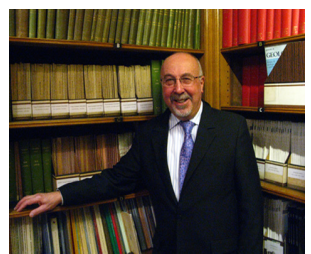

Edmund Nickless Edmund is a geologist by training and has worked extensively on assessment of industrial mineral resources. From 1997 until his retirement in September 2015 he was Executive Secretary of The Geological Society of London. Previous to that, he held senior posts within the British Geological Survey, the then Science and Technology Secretariat of the Cabinet Office where he was environmental adviser, and the Natural Environment Research Council where he was responsible for research grants, training awards and UK participation in international programmes, principally the Ocean Drilling Program and its successors. Since 2013 he has chaired a group on behalf of IUGS promoting a new initiative, Resourcing Future Generations and is currently an IUGS Councillor. He is a Fellow of the Geological Society of London, a Fellow of the Geological Society of America, a Chartered Scientist, Chartered Geologist and European Geologist. 